\title{
Liner Production of Florida Native Wildflowers by Seed ${ }^{\mathbf{1}}$
}

Jeffrey G. Norcini and James H. Aldrich ${ }^{2}$

Demand for native wildflowers and grasses has increased over the past 15 to 20 years as a result of the surge in interest in use of native species, especially native plants that are adapted to Florida conditions. Growers of native plants are trying to keep up with demand but frequently have to work out production protocols because such information is limited.

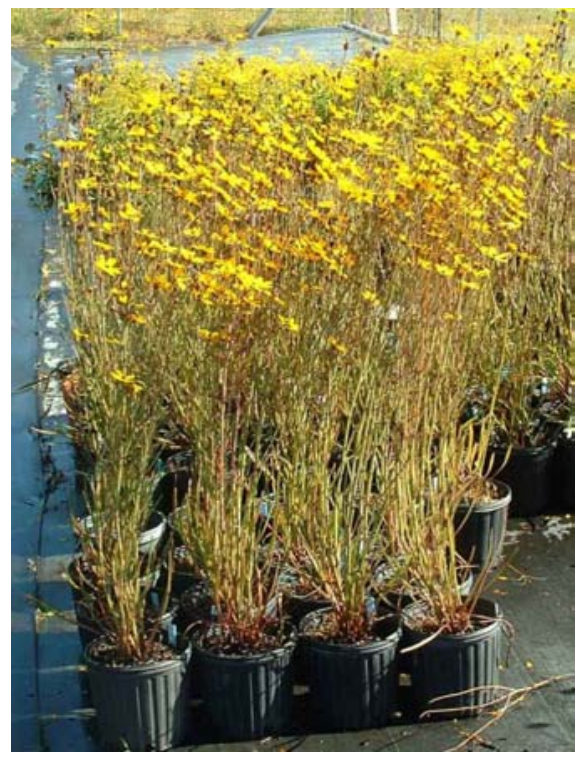

Figure 1. Container-grown Florida coreopsis at the NFREC-Quincy, November 2007.
In this publication we describe in detail the methods that we have successfully used to produce liners of Florida native wildflowers (Table 1) under greenhouse conditions. Information is based on production of -inch" liners that could be sold or used as transplants in 4-inch, 1-qt. or 1-gal. containers (Fig. 1), or they could be transplanted to the field.

While this information is based on our experience with non-varietal germplasm, the methods would be suitable for use with many types of wildflower seeds.

\section{Seeds}

Seeds can be harvested from cultivated plants or directly from plants in the wild. Seeds not sown within a few days of harvest should be dried at $\sim 30$ to $40 \%$ relative humidity at room temperature for 10 to 14 days, placed in an air-tight container or plastic freezer bag, and stored in a refrigerator or freezer until needed. When removing seeds from cold storage, allow the container to become room temperature before opening it.

\footnotetext{
1. This document is ENH1087, one of a series of the Environmental Horticulture Department, Florida Cooperative Extension Service, Institute of Food and Agricultural Sciences, University of Florida. Original publication date December, 2007. Visit the EDIS Web Site at http://edis.ifas.ufl.edu.

2. Associate Professor, native wildflower specialist, and Senior Biological Scientist, North Florida Research \& Education Center, Quincy, FL 32351.

The use of trade names in this publication is solely for the purpose of providing specific information. UF/IFAS does not guarantee or warranty the products named, and references to them in this publication does not signify our approval to the exclusion of other products of suitable composition.
} 


\section{Seeds (continued)}

\section{Special Cases}

\section{Gayfeathers (Liatris spp.)}

Seeds of gayfeathers (blazing stars) need to be subjected to cold, moist conditions (cold stratification) prior to sowing. First, soak Canadian sphagnum peat moss or cotton in water. The peat moss should be the shredded type commonly sold in compressed bales. Peat moss will need to soak in water overnight to become thoroughly moistened. Remove excess moisture to ensure the peat moss or cotton is not too wet. Mix the seed with the moistened peat or cotton, place the mixture in a container, and seal to prevent the drying. Plastic food storage bags work well. Put the container in a refrigerator for 6 to 10 weeks. The stratification process will be complete when seeds start to germinate. For more information about stratification, see "Propagation of Landscape Plants (1).

\section{$\underline{\text { Swamp or Pink Coreopsis (Coreopsis nudata) }}$}

Harvest seed heads soon after the petals drop off and while the seed heads are green or reddish green. Break up the seed heads by hand and sow the green, immature seeds the same day of harvest.

\section{Liner Production}

Sow seeds about 2 months before finished liners are needed. For spring-flowering species to be ready in March in north Florida, sow seeds the first or second week of January. For fall-flowering species, sow seeds in mid-spring to mid-summer.

The later that seeds are sown, the smaller the liners will be when ready for sale, repotting, or transplanting (Fig. 2). Delayed seeding is used to ensure that liners of tall species like Florida coreopsis (Coreopsis floridana) do not outgrow containers and to minimize the likelihood of the plants falling over because they are top heavy.

Fill seedling flats with fine-textured, soilless substrate designed for germinating seed, such as

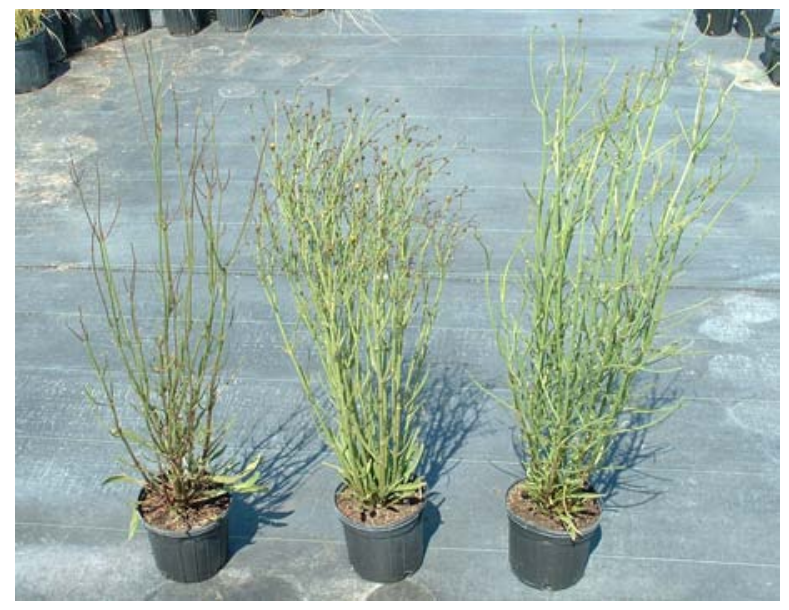

Figure 2.a

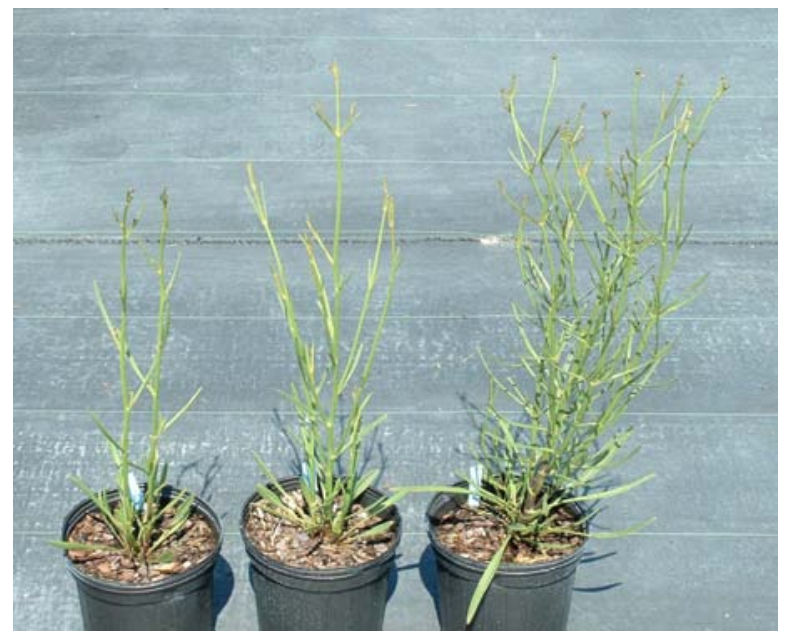

Figure 2.b

Figure 2. Height of the fall-flowering Florida coreopsis was controlled by sowing date. Plants produced from seeds sown in January (2a) were too tall and top heavy. Plants produced from seeds sown in May (2b) were of a more desirable height for commercial producers. Images were recorded in late September, a few weeks before these plants flowered. Also note the effect of increasing rates of controlled-release fertilizer (left to right).

Metro Mix $200^{\circledR}$. Substrates such as Metro Mix $200^{\circledR}$ are fine textured enough to ensure contact with the seeds and retain moisture for germination yet drain freely. Spread seeds as uniformly as possible over the surface of the substrate, and then lightly spread some dry substrate over the seeds. This light covering of substrate enhances seed uptake of moisture but still allows seeds to be exposed to light. Many wildflowers have small seeds that require light for germination. Small-seeded species may germinate, but not emerge if planted too deeply. 
Flats with seeds are then placed on thermostatically controlled propagation mats $\left(70^{\circ} \mathrm{F}\right)$ to ensure that the substrate temperature remains warm, which will facilitate germination and emergence. A single 22 -inch $x$ 60-inch propagation mat will accommodate approximately five flats while two mats side-by-side will accommodate approximately 11 flats. To facilitate drainage, mats can be placed on slanted boards that are at approximately a $30^{\circ}$ angle. Greenhouse thermostats are set at $50^{\circ} \mathrm{F}$ and $90^{\circ} \mathrm{F}$ for heating and cooling (fan and pad), respectively. Irrigate flats so that the substrate remains moist. An automated, overhead mist system will ensure that substrate remains moist without disturbing the seeds or seedlings.

Weekly fertigation is started when most seedlings have emerged, which is about 10 to 14 day after seeds were sown. To minimize seedling disturbance, seedlings are fertigated from the bottom by placing flats in 11-inch $\mathrm{x} 21$-inch $\mathrm{x}$ 4-inch (or larger) tubs containing a 100-ppm-N solution of a 15-30-15 water-soluble fertilizer. Once the surface of the substrate glistens with a film of water, flats are removed and drained.

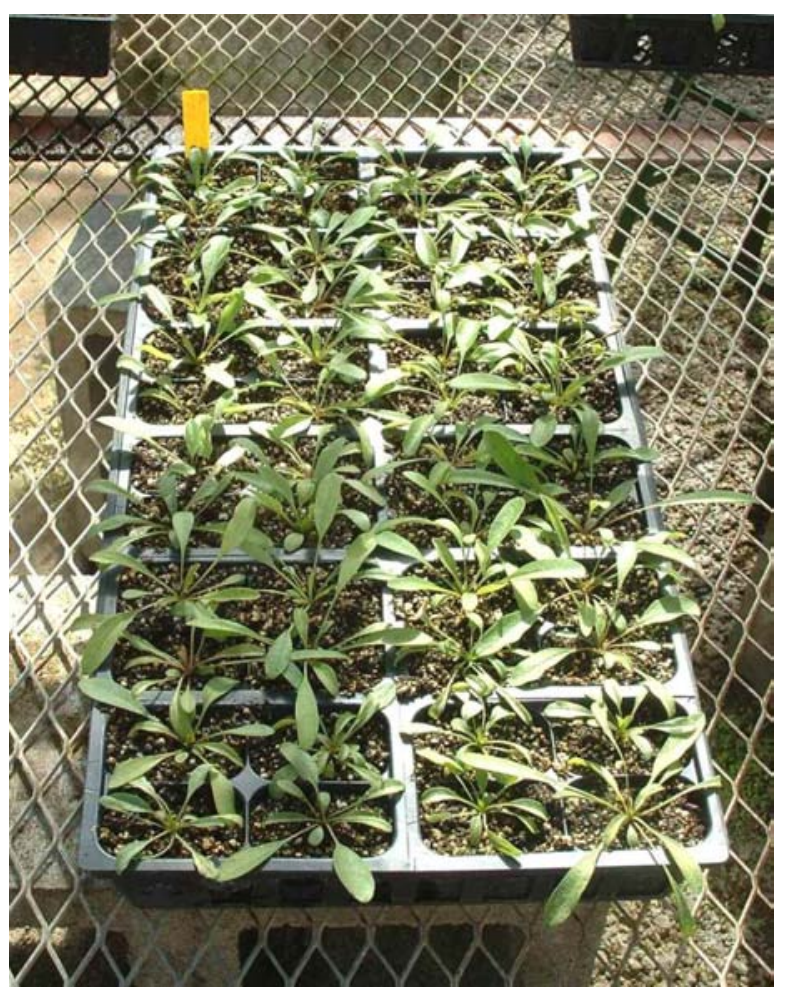

Figure 3. Lanceleaf coreopsis seedlings in flats of -inch" cells.
About 1 month after seeds are sown, transplant seedlings into cell packs that are composed of 48 -inch" cells (actual dimensions are 2 1/4 inches x 1 $5 / 8$ inches $\times 21 / 4$ inches) and are filled with the same substrate used for germinating the seedlings (Fig. 3).

These cell packs fit within a 11 -inch x 21-inch flat. Fertigate seedlings weekly as described before.

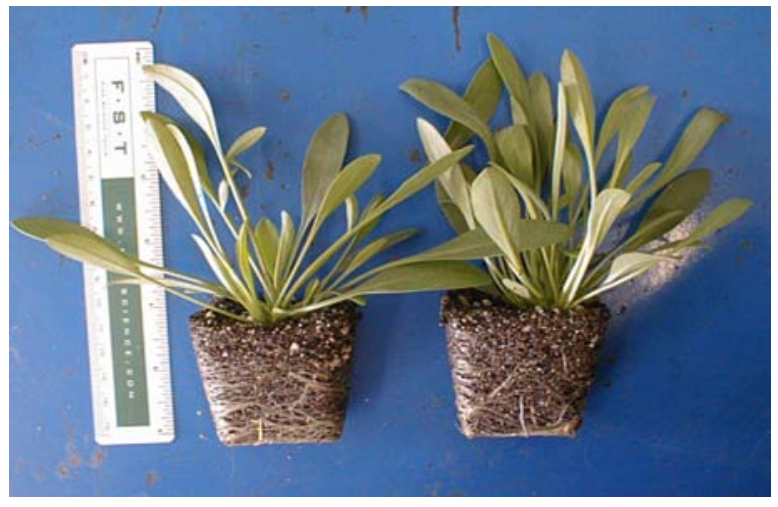

Figure 4. Liners of lanceleaf coreopsis ready for sale or transplanting. Total production time from seed sowing to finished liner was about 2 months.

After 1 month, seedlings in cell packs (Fig. 4) are ready for sale or transplanting to 4-inch, 1-qt. or 1-gal. containers, or they can be transplanted to a field production site.

NOTE: In central and south Florida, liner production times might be compressed by a week or two due to warmer temperatures.

\section{References}

1. Ingram, D.L. and T.H. Yeager. 1991. Propagation of landscape plants. Florida Coop. Ext. Serv. Publ. CIR579. http://edis.ifas.ufl.edu/MG108 
Table 1. Native wildflower and grass liners produced using the methods described in this publication.

\begin{tabular}{||l|l||}
\hline \hline Latin name & Common name(s) \\
\hline Coreopsis basalis & Goldenmane Coreopsis \\
\hline Coreopsis floridana & Florida Coreopsis \\
\hline Coreopsis grandiflora & Largeflower Coreopsis \\
\hline Coreopsis lanceolata & Lanceleaf Coreopsis \\
\hline Coreopsis leavenworthii & Leavenworths Coreopsis \\
\hline Coreopsis nudata & Swamp Coreopsis \\
\hline Coreopsis pubescens & Star Coreopsis \\
\hline Coreopsis tinctoria & Golden Coreopsis \\
\hline Flaveria linearis & Narrowleaf Yellowtops \\
\hline Gaillardia pulchella & Firewheel, Blanketflower, Indian Blanket \\
\hline Ipomopsis rubra & Standing Cypress, Spanish Larkspur \\
\hline Liatris spicata & Dense Gayfeather \\
\hline Phlox drummondii & Drummond Phlox, Annual Phlox \\
\hline Ratibada pinnata & Pinnate Prairie Coneflower \\
\hline Rudbeckia hirta & Blackeyed Susan \\
\hline Rudbeckia mohrii & Mohrs Coneflower \\
\hline Rudbeckia mollis & Softhair Coneflower \\
\hline Tridens flavus (grass) & Tall Redtop, Purpletop Tridens \\
\hline \hline
\end{tabular}

